University of New Hampshire

University of New Hampshire Scholars' Repository

$6-2008$

\title{
Is talking online to unknown people always risky? Distinguishing online interaction styles in a national sample of youth Internet users.
}

Janis Wolak

University of New Hampshire - Main Campus

David Finkelhor

University of New Hampshire - Main Campus, David.Finkelhor@unh.edu

Kimberly J. Mitchell

University of New Hampshire - Main Campus

Follow this and additional works at: https://scholars.unh.edu/soc_facpub

Part of the Psychology Commons, and the Sociology Commons

\section{Recommended Citation}

Wolak, J., Finkelhor, D., Mitchell, K. Is talking online to unknown people always risky? Distinguishing online interaction styles in a national sample of youth Internet users. (2008) Cyberpsychology and Behavior, 11 (3), pp. 340-343.

This Article is brought to you for free and open access by the Sociology at University of New Hampshire Scholars' Repository. It has been accepted for inclusion in Sociology Scholarship by an authorized administrator of University of New Hampshire Scholars' Repository. For more information, please contact Scholarly.Communication@unh.edu. 


\title{
Rapid Communication
}

\section{Is Talking Online to Unknown People Always Risky? Distinguishing Online Interaction Styles in a National Sample of Youth Internet Users}

JANIS WOLAK, J.D., DAVID FINKELHOR, Ph.D., and KIMBERLY MITCHELL, Ph.D.

\begin{abstract}
We examined the risk of unwanted online sexual solicitations and characteristics associated with four online interaction styles among youth Internet users. The interaction styles took into account the people with whom youth interacted online (people known in person only, unknown people met through face-to-face friends, unknown people met in chatroom, and other places online) and high- and low-risk patterns of online behavior. The aim was to provide a basis for identifying which youth may be most at risk from interacting online with unknown people.
\end{abstract}

\section{METHODS}

$\mathbf{T}$ HE DATA WERE GATHERED in a telephone survey of a nationally representative sample of 1,500 youth Internet users ages 10 to 17 years, conducted between March and June 2005. A detailed description of the sample and methodology can be found in other publications. ${ }^{1,2}$

\section{MEASURES}

We asked the youth nine questions about interacting online with others. The first five questions concerned people they knew in person. "People use the Internet to communicate with a lot of different individuals. In the past year, have you communicated online with (1) people your age you see often, like friends from school? (2) people your age you don't see often, like friends who have moved away?
(3) people in your family you see often? (4) people in your family you don't see often, like relatives who live in other places? (5) other people you know personally, like teachers or coaches or neighbors?"

The next four questions concerned unknown people. "People also communicate with individuals they only know from the Internet, whom they don't know in person. In the past year, have you been online with (6) people you don't know in person, but you met online through friends or family-for example, a friend introduced you to someone through email? (7) people you get information from, like when you're working on school projects, but you don't know them in person? (8) people you met through an online dating or romance site? (9) people you don't know in person, whom you know online other ways-for example, people you met chatting or through instant messages?"

Youth who answered yes to any of the first five questions and no to questions 6 through 9 were

Crimes against Children Research Center, University of New Hampshire, Durham, New Hampshire. 
coded as cautious interactors. Youth who answered yes to question 6 and no to questions 7 through 9 were coded as friend-mediated interactors. Youth who answered yes to any of questions 7 through 9 were coded as unrestricted interactors.

The measure that distinguished high- versus lowrisk unrestricted interactors was based on analyses developed by Ybarra et al., ${ }^{3}$ which found increases in online harassment and unwanted sexual solicitation based on the number of different potentially risky online behaviors youth had engaged in during the past year. The behaviors are listed in Table 1. The number of behaviors was summed, and youth who scored at least $1 \mathrm{SD}$ above the mean $(M=2.5, S D=2.1)$ by engaging in five or more different behaviors were deemed high risk.

Aggressive online sexual solicitations were unwanted sexual solicitations (e.g., requests to talk about sex, give sexual information, or do something sexual) involving attempts at or actual offline contact by the solicitor. The variables describing demographic, Internet use and psychosocial characteristics are described in detail in other publications. ${ }^{1,2}$

\section{RESULTS}

Of youth Internet users who interacted online with other people, $17 \%$ were high-risk unrestricted interactors who engaged in high levels of potentially risky online behaviors (see Table 1). Twenty- one percent were low-risk unrestricted interactors; $10 \%$ were friend-mediated interactors; and 51\% were cautious interactors who interacted online only with people they knew in person.

Fifteen percent of high-risk unrestricted interactors had received aggressive solicitations, compared to $6 \%$ of the low-risk, $4 \%$ of the friend-mediated, and $1 \%$ of the cautious groups. The high-risk youth had significantly higher rates of every type of potentially risky online behavior. In particular, 25\% had talked online to unknown people about sex, compared to $4 \%$ of the low-risk group and $5 \%$ of the friend-mediated group.

Bivariate comparisons of high- and low-risk unrestricted, friend-mediated, and cautious interactors showed demographic differences in terms of age, family structure, and race among the four groups, as well as significant differences in many of the Internet use and psychosocial characteristics assessed (see Table 2).

Using multinomial logistic regression comparing high-risk unrestricted interactors to cautious ones, we found that high-risk unrestricted interactors were more likely to be teenagers, have high levels of Internet use, and engage in most types of interactive Internet use (see Table 2). They were more likely to report offline interpersonal victimization such as physical assaults by siblings or being bullied. They were over four times more likely to score in the borderline or clinically significant range on the Child Behavior Checklist (CBCL) subscales for

Table 1. Aggressive Sexual Solicitations and Types of Risky Online Behavior by Interactor Group

\begin{tabular}{|c|c|c|c|c|}
\hline Characteristics & $\begin{array}{c}\text { High-risk } \\
\text { unrestricted } \\
\text { interactors } \\
(\mathrm{n}=228) \\
\%\end{array}$ & $\begin{array}{c}\text { Low-risk } \\
\text { unrestricted } \\
\text { interactors } \\
(\mathrm{n}=281) \\
\%\end{array}$ & $\begin{array}{c}\text { Friend- } \\
\text { mediated } \\
\text { interactors } \\
(\mathrm{n}=136) \\
\%\end{array}$ & $\begin{array}{c}\text { Cautious } \\
\text { interactors } \\
(\mathrm{n}=682) \\
\%\end{array}$ \\
\hline Received aggressive solicitation*** & $15^{\mathrm{a}}$ & 6 & 4 & 1 \\
\hline \multicolumn{5}{|l|}{ Types of potentially risky online behavior } \\
\hline Interacted online with unknown people ${ }^{\text {na }}$ & 100 & 100 & 100 & 0 \\
\hline Posted personal information or picture online ${ }^{* * *}$ & $93^{\mathrm{a}}$ & 58 & 75 & 48 \\
\hline Sent personal info/picture to unknown person ${ }^{* * *}$ & $93^{\mathrm{a}}$ & 39 & 49 & 0 \\
\hline People on buddy list never met in person ${ }^{* * *}$ & $90^{\mathrm{a}}$ & 47 & 60 & 15 \\
\hline Made rude or nasty comments online ${ }^{* * *}$ & $79^{\mathrm{a}}$ & 22 & 40 & 18 \\
\hline Used file sharing software to download images*** & $47^{\mathrm{a}}$ & 8 & 17 & 9 \\
\hline Visited X-rated Web site on purpose ${ }^{* * *}$ & $39^{\mathrm{a}}$ & 7 & 14 & 9 \\
\hline Harassed or embarrassed someone mad at ${ }^{* * *}$ & $27^{\mathrm{a}}$ & 3 & 15 & 5 \\
\hline Talked about sex to person met online ${ }^{* * *}$ & $25^{\mathrm{a}}$ & 4 & 5 & 0 \\
\hline High level of risky behaviors (five or more) ${ }^{\text {na }}$ & 100 & 0 & 32 & 1 \\
\hline
\end{tabular}

${ }^{a} p \leq 0.001$, comparing low- and high-risk unrestricted interactors only.

naSignificance tests not applicable.

${ }_{* * *}^{*} \leq 0.001 ;{ }^{* *} p \leq 0.01$; comparing all four categories. 
Table 2. Bivariate And Multivariate Comparisons of Characteristics of Cautious, Friend-MEdiated AND LOW AND High RisK UNRESTRICTED INTERACTORS

\begin{tabular}{|c|c|c|c|c|}
\hline Characteristics & $\begin{array}{c}\text { High-risk } \\
\text { unrestricted } \\
\text { interactors } \\
(\mathrm{n}=228) \\
\%\end{array}$ & $\begin{array}{c}\text { Low-risk } \\
\text { unrestricted } \\
\text { interactors } \\
(\mathrm{n}=281) \\
\%\end{array}$ & $\begin{array}{c}\text { Friend- } \\
\text { mediated } \\
\text { interactors } \\
(\mathrm{n}=136) \\
\%\end{array}$ & $\begin{array}{c}\text { Cautious } \\
\text { interactors } \\
(\mathrm{n}=682) \\
\%\end{array}$ \\
\hline \multicolumn{5}{|l|}{ Demographic characteristics } \\
\hline Teenager $(13-17 \text { years old })^{* * *}$ & $96^{a}$ & 79 & 82 & 75 \\
\hline Female & 47 & 52 & 51 & 55 \\
\hline $\begin{array}{l}\text { Household education some } \\
\text { college or more }\end{array}$ & 54 & $48^{c}$ & 58 & 59 \\
\hline Household income $\$ 20,000$ or less & 8 & 9 & 5 & 7 \\
\hline Household income $>\$ 75,000$ & 33 & 29 & 38 & 37 \\
\hline Lives with both biological parents ${ }^{* * *}$ & 61 & 53 & 65 & 66 \\
\hline White race ${ }^{* * *}$ & 79 & $66^{\mathrm{b}}$ & 87 & 80 \\
\hline Black race r** $^{* *}$ & 13 & 22 & 7 & 9 \\
\hline Hispanic ethnicity & 8 & 11 & 7 & 8 \\
\hline \multicolumn{5}{|l|}{ Internet use characteristics } \\
\hline High level of Internet use ${ }^{* * *}$ & $54^{\mathrm{a}}$ & 29 & $41^{b}$ & 21 \\
\hline Low level of Internet use $\mathrm{e}^{* * *}$ & $6^{\mathrm{c}}$ & 19 & $9^{c}$ & 23 \\
\hline Had Internet access at home $e^{* * *}$ & 97 & 87 & 93 & 94 \\
\hline Used Internet at friends' homes*** & 86 & 71 & 83 & 68 \\
\hline \multicolumn{5}{|l|}{ What youth did online } \\
\hline Used e-mail ${ }^{* * *}$ & $97^{\mathrm{c}}$ & 85 & 88 & 84 \\
\hline Used instant messaging ${ }^{* * *}$ & $95^{a}$ & 71 & $84^{c}$ & 71 \\
\hline Went to chat rooms $s^{* * *}$ & $62^{\mathrm{a}}$ & $51^{\mathrm{a}}$ & $33^{a}$ & 17 \\
\hline Played games*** & $88^{c}$ & $87^{\mathrm{b}}$ & $88^{c}$ & 79 \\
\hline Kept an online journal or blog*** & 30 & 18 & 21 & 14 \\
\hline \multicolumn{5}{|l|}{ Psychosocial characteristics } \\
\hline High parent-child conflict*** & 23 & 18 & 11 & 10 \\
\hline Sexual or physical abuse, past year & 6 & 4 & 5 & 2 \\
\hline $\begin{array}{l}\text { Offline interpersonal victimization, } \\
\text { past year }\end{array}$ & $56^{\mathrm{a}}$ & 42 & $47^{\mathrm{b}}$ & 31 \\
\hline \multicolumn{5}{|l|}{$\begin{array}{l}\text { CBCL subscales (scored in borderline or } \\
\text { clinically significant range) }\end{array}$} \\
\hline Aggressive behavior*** & 15 & 7 & 6 & 3 \\
\hline Rule-breaking behavior ${ }^{* * *}$ & $18^{\mathrm{a}}$ & 6 & 7 & 3 \\
\hline Social problems*** & $11^{\mathrm{b}}$ & 7 & $8^{c}$ & 3 \\
\hline Withdrawn/depressed ${ }^{* * *}$ & $8^{a}$ & $7^{\mathrm{a}}$ & 4 & 1 \\
\hline
\end{tabular}
${ }^{\mathrm{a}} p \leq 0.001,{ }^{\mathrm{b}} p \leq 0.01 ;{ }^{c} p \leq 0.05$.

Note: Boldface denotes variables significant in backward stepwise multinomial logistic regression. Regression controlled for all variables significant in bivariate analyses. Reference category is cautious interactors. Nine cases were dropped from the regression due to missing data on some variables.

$-2 \log$ likelihood $=2110.796$, Model chi-square $(\mathrm{df} 39)=515.151, \mathrm{R} 2($ Cox \& Snell) $=.324$, R2 (Nagelkerke) $=.355$.

${ }^{* * *} p \leq 0.001 ;{ }^{* *} p \leq 0.01$ in bivariate analyses, comparing all four categories.

rule-breaking behavior (AOR 4.9, 95\% CI 2.7-8.5) and depression (AOR 4.7, 95\% CI 1.9-11.1) and more than twice as likely to exhibit social problems (AOR 2.7, 95\% CI 1.3-5.4). (Odds ratios are adjusted to correct for over-estimation of risk). ${ }^{4}$

\section{DISCUSSION}

Internet safety messages often suggest that interacting online with unknown people in any circumstance is risky for youth Internet users because it 
may invite unwanted sexual solicitations that could lead to sexual victimization. Our findings suggest that many youth interact online with unknown people with little such risk. The youth most at risk included those with a diverse range of problems, including rule-breaking behavior, depression, and social problems that may manifest in different respects in interactions with unknown people. Rather than issuing blanket warnings to youth not to converse online with unknown people, more nuanced messages should be developed and targeted at the youth most at risk.

\section{ACKNOWLEDGMENT}

To comply with Section 507 of PL 104-208 (the "Stevens Amendment"), we advise readers that $100 \%$ of the funds for this research were derived from federal sources, through Grant No. 2005-MCCX-K024 from the Office of Juvenile Justice and Delinquency Prevention, U.S. Department of Justice, and Grant No. HSCEOP-05-P-00346 from the U.S. Secret Service, Department of Homeland Security. The total amount of federal funding is $\$ 348,767$. Points of view or opinions in this document are those of the authors and do not necessarily represent the official position or policies of the U.S. De- partment of Justice or Department of Homeland Security.

\section{REFERENCES}

1. Mitchell KJ, Wolak J, Finkelhor D. Trends in youth reports of sexual solicitations, harassment and unwanted exposure to pornography on the Internet. Journal of Adolescent Health 2007; 40:116-26.

2. Wolak J, Mitchell K, Finkelhor D. (2006) Online victimization: 5 years later. Alexandria, VA: National Center for Missing \& Exploited Children.

3. Ybarra ML, Mitchell KJ, Wolak J, Finkelhor D. Internet prevention messages: targeting the right online behaviors? Archives of Pediatrics and Adolescent Medicine 2007; 161:138-45.

4. Zhang J, Yu KF. What's the relative risk? A method of correcting the odds ratio in cohort studies of common outcomes. Journal of the American Medical Association 1998; 280:1690-1.

Address reprint requests to: Janis Wolak Crimes against Children Research Center University of New Hampshire 10 West Edge Drive, Suite 106 Durham, New Hampshire 03824

E-mail: Janis.Wolak@unh.edu 


\section{This article has been cited by:}

1. Leslie HaddonSocial Media and Youth 1-9. [CrossRef]

2. Linda S. Jonsson, Marie Bladh, Gisela Priebe, Carl Göran Svedin. 2015. Online sexual behaviours among Swedish youth: associations to background factors, behaviours and abuse. European Child \& Adolescent Psychiatry . [CrossRef]

3. Sonia Livingstone, Peter K. Smith. 2014. Annual Research Review: Harms experienced by child users of online and mobile technologies: the nature, prevalence and management of sexual and aggressive risks in the digital age. Journal of Child Psychology and Psychiatry 55:10.1111/jcpp.2014.55.issue-6, 635-654. [CrossRef]

4. Sonia Livingstone, Anke Görzig. 2014. When adolescents receive sexual messages on the internet: Explaining experiences of risk and harm. Computers in Human Bebavior 33, 8-15. [CrossRef]

5. Jennifer E. Simpson. 2013. A divergence of opinion: how those involved in child and family social work are responding to the challenges of the Internet and social media. Child \& Family Social Work n/a-n/a. [CrossRef]

6. Monica Barbovschi. 2013. Children's Meetings Offline with People Met Online:. Journal of Children and Media 7, $28-43$. [CrossRef]

7. Sook-Jung Lee, Young-Gil Chae. 2012. Balancing Participation and Risks in Children's Internet Use: The Role of Internet Literacy and Parental Mediation. Cyberpsychology, Bebavior, and Social Networking 15:5, 257-262. [Abstract] [Full Text HTML] [Full Text PDF] [Full Text PDF with Links]

8. Piotr S. Bobkowski, Jane D. Brown, Deborah R. Neffa. 2011. "Hit me up and we can get down”. Journal of Children and Media 1-16. [CrossRef]

9. Susanne E. Baumgartner, Patti M. Valkenburg, Jochen Peter. 2010. Assessing Causality in the Relationship Between Adolescents' Risky Sexual Online Behavior and Their Perceptions of this Behavior. Journal of Youth and Adolescence 39, 1226-1239. [CrossRef]

10. Shu-Sha Angie Guan, Kaveri Subrahmanyam. 2009. Youth Internet use: risks and opportunities. Current Opinion in Psychiatry 22, 351-356. [CrossRef]

11. Susanne E. Baumgartner, Patti M. Valkenburg, Jochen PeterUnwanted Online Sexual Solicitation and Online Sexual Risk Behavior 828-836. [CrossRef]

12. Online Child Predators 133-152. [CrossRef] 